\title{
Between Legacy and Revival: A Postmodern Reading of Mary Shelly's Frankenstein and Ahmed Saadawi's Frankenstein in Baghdad $^{1}$
}

Rania Reda Nasr

\footnotetext{
${ }^{1}$ An early version of this paper was first presented under the title "Representations of Violence in Ahmed Saadawi's Frankenstein in Baghdad" at NeMLA: Northeast Modern Language Association's 46 Annual Convention, Toronto, Canada, 2015.
} 


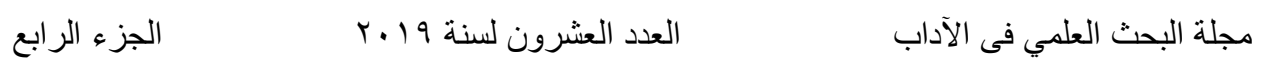

\begin{abstract}
Throughout two hundred years, Mary Shelly's revolutionary novel Frankenstein continues to fascinate and inspire generations yet to come. Being adapted and appropriated into wholly new cultural and political domains, Shelly's genuine work of art never ceases to reveal the anxieties of everyday life throughout history. Reviving Shelly's legacy and appropriating it into a wholly new context, the Iraqi writer Ahmed Saadawi offers us an insight into the violence and terror of everyday life in Iraq under the 2003 US occupation and the wake of the civil war in his award-winning novel Frankenstein in Baghdad. The novel is a "shock" in the realm of the Arabic fiction, a shock in the way it was written and a shock in its daring way to deal with reality and addressing the repressed fears, anxieties and desires of different sects in the society. Interweaving fantasy and reality, Saadawi's novel blurs the lines between good and evil, criminals and victims, life and death. By revisiting Shelly's legacy, this paper aims to explore the impact of the Western "hypotext" upon Saadawi's Arabic "hypertext" within a postmodern frame of study.
\end{abstract}

Keywords: Frankenstein, Mary Shelley, Ahmed Saadawi, postmodernism, gothic, abject, uncanny, violence, power, terror, horror, adaptation, appropriation.

$* * * * * * *$

I discovered what writers have always known ( and have told us again and again): books always speak of other books, and every story tells a story that has already been told... (Umberto Eco, The Name of the Rose)

As I approached the arch I began to perceive the presence more clearly; and then, with the first and last sound I ever uttered - a ghastly ululation that revolted me almost as poignantly as its noxious cause - I beheld in full, frightful vividness the inconceivable, indescribable, and unmentionable monstrosity ... to my horror I saw in its eaten-away and bone-revealing outlines a leering, abhorrent travesty on the human shape ... My fingers touched the rotting outstretched paw of the monster ... stretched out my fingers and touched a cold and unyielding surface of polished glass. (H.P. Lovecraft, "The Outsider")

Throughout history, every age is marked by recognizable features that distinguish it from other ages. Every age is identified with distinct and prominent figures in different genres whether in literature, art, music, science, philosophy, or other fields. Movements rise and fall and theorists come and go and what remains is the text, waiting for us to recall and 


$$
\begin{aligned}
& \text { الجزء الر ابع } \\
& \text { العدد العشرون لسنة } 9 \text { بـ }
\end{aligned}
$$

revisit it, inviting and calling upon the imagination to be set free and to produce endless interpretations to it. In our world today that is marked by endless explorations, knowledge is free and accessible everywhere. The world has become one and boundaries have vanished. World literature today has exceeded all boundaries and showered us with endless and priceless stories from different genres. The aim of this paper is to cross these boundaries in time and space in an attempt to revisit the legendary myth of Mary Shelley's Frankenstein (1818) and explore it within postmodernist hybrid textures. Throughout two centuries, Shelly's masterpiece continues to be adapted into movies, plays, artistic and literary texts; it continues to charm and inspire its readers. In an analogous and comparative approach, this paper will explore how the contemporary Iraqi writer Ahmed Saadawi was inspired by Shelly's myth and appropriates it into his award-winning novel, Frankenstein in Baghdad (2013).

To understand the term postmodernism is a very challenging task, for it does not emerge as a cohesive movement as its predecessors. Theorists and critics in every literary genre and field contributed greatly to identify its characteristics and unravel its complexities. The simplest form was to face Postmodernism in contrast to Modernism. In his critical study, "Modernism and Postmodernism", Terry Barrett argues that postmodernism "does not merely chronologically follow modernism, it reacts against modernism, and it might better be called anti-modernism" (17). One of the main features of Modernism is their disregard of history and the past, advocating for innovation and what is new. Postmodernism criticizes this trend and calls for revisiting history and borrowing from the past, merging the old with the new and creating new meaning and new contexts. Postmodernism is, thus, set in confrontation of "the formerly oppositional modern movement as a set of dead classics" (Jameson, 4). This summoning of the past does not replace original texts, but simply reacts to them and effectively create their own response. Postmodernism resists dominant "meta-narratives", drawing attention to the alternative narratives of the marginalized and the omitted voices, those who have been "excluded" the "different or the other" (Hutcheon, "Postmodernism", 120) 2 .

\footnotetext{
${ }^{2}$ Christopher Butler proposes the example of Edward Said who, in Orientalism, resisted the Western grand narratives upon oriental societies, "for the imperialist saw himself as the representative of a rational, ordered, peaceful, and law-abiding framework, and defined the Orient as the opposite of this, and had the confidence that his representation of 'them' - his narrative of 'Orientalism' - would prevail" (Butler, 15-16).
} 
In her critical study on postmodernism, Linda Hutcheon states that the term postmodernism 'carries within itself the 'modern' - from which it both derives and deviates. It is 'post' in the sense of temporarily 'after' and conceptually "beyond" (Hutcheon, "Postmodernism", 117). Postmodernism is thus an umbrella term that denotes various ambiguous and diverse modes where the old is revisited and binaries are deconstructed. The works of the postmodernists are thus "doubly coded" and paradoxical, that is "new and modern, but also historical ... a paradoxical mixing of seemig opposites: the traditional and the new ... it was both a break from and a continuation of what had come before" (Hutcheon, "Postmodernism", 115, 121). Postmodernist texts are a mosaic of hybrid artistic creations of familiar and diverse modes, inviting the imagination to play, re-interpret and re-vision for the future.

\section{Gothic Postmodernism and the Literature of Terror:} In his profound study The Literature of Terror, David Punter states that the Gothic originated primarily to create a terrifying mood within archaic settings, haunted castles through the use of ghosts, vampires and monsters. The use of the supernatural played upon psychological obsessions within distorted settings echoing the styles of graveyards, death, mystery, dark atmosphere and heavy mood, and the haunting undertones of literary expressions (Punter, 1-20). He simply states that "exploring Gothic is also exploring fear" (18). Originally, the Gothic had negative connotations referring to something that "appeared dark and barbarous" (Varma, 10). Having lost "its older intensity," (Hogle, 287) this traditional concept gradually changed as the term came to signify "a valuable imaginative freedom" (Kilgour, 14) as the mind flies freely displaying a fascination with the "irrational," the "immoral," and the "fantastic" (Botting, 2). It is a "writing of excess" (Botting, 1) that is evoked mainly to arouse fear. In this regard, Robert Hume maintains that "the key characteristic of the Gothic novel is not its devices but it atmosphere $\ldots$ one of evil and brooding terror" (286).

In her groundbreaking study, Gothic- postmodernism, Maria Beville offers new insights on "gothic-postmodernism. Beville asserts that the "gothic" is "the clearest mode of expression in literature for voicing the terrors of postmodernity" (Beville, 8 ). While the Gothic could be seen as old and exhausted, Beville offers a new perception as "terror" is deeply entrenched in postmodernity. Gothic-postmodernism is,

a luminal genre, existing on the margins between reality and unreality, self and other, fear and desire, reason and unreason, between past, present and future. It often traverses these 
boundaries and so functions as a 'third space' in literary representations. (Beville, 96)

Moreover, Beville states that the Gothic has long provided an "outlet" for the expression of fears aroused by terror while also "playing a significant role in the creation of terror itself" (33).

On his behalf, Stephen King identifies three categories of fear: terror, horror and revulsion. He argues that terror arises when the readers do not see the source of fright but are left to imagine fearful things hidden from sight (21). Horror happens when the readers are actually shown a creature abnormal or different (22). Finally, revulsion occurs when the written language attempts to shock its readers with disgusting descriptions aiming to disturb them and create repulsion (23). In this sense, King argues that the most significant is the "terror" of things unseen but suggested: "it is what the mind sees that makes these stories such quintessential tales of terror" (36). In this regard, Fred Botting states that "if terror leads to an imaginative expansion of one's sense of self, horror describes the moment of contraction and recoil" (10). Furthermore, Beville argues that horror is a "limiting experience" as it present the horrifying event in full and grotesque detail, causing the imagination "to shrink and recoil" (89) while terror merely "hints" at the evil and the grotesque and by which "opens up a space for fundamental human curiosity, and ontological inquiry" (42). The difference between terror and horror, to put it in other words, is "the difference between the smell of death and the stumbling against a corpse" (Varma, 130).

From a postmodern perspective, these feelings of terror and horror are paradoxically mingled with fascination or, as Punter puts it, represent "the dreadful pleasure" (7). Such terrors were also the source of pleasure, "stimulating excitements which blurred definitions of reason and morality" (Botting, 6). Botting further states,

The emotions most associated with Gothic fiction are similarly ambivalent: objects of terror and horror not only provoke repugnance, disgust and recoil, but also engage readers' interest fascinating and attracting them. Threats are spiced with thrills, terrors with delight, horrors with pleasures. (9)

Accordingly, Gothic postmodernists reveal to us dark and disturbing views of ourselves and our society displaying through "the language of terror" (Foucault, 65) our repressed fears and forbidden desires. Their 
stories become "literary monsters" (Beville, 16) and serve as a mirror to shock us and force us to face ourselves. In this sense, we can behold Gothic postmodernist narratives as counter-narratives and Gothic postmodernism as a revolutionary discourse in the sense that they alter reality by forcing us to deal with our repressed unconsciousness and by using the "language of terror" to display one's "personal experience" with terror, providing an "outlet" for imaginative energy.

In his psychological study, "The Uncanny," Sigmund Freud attempts to explain a particular kind of fear that he classifies as the "uncanny", that "class of the frightening which leads back to what is known of old and long familiar" (20). The uncanny in gothic narratives does not appear, then, as something which is "new" or "alien," but something which is "familiar and old established in the mind" and which was repressed for so long (Freud, 241). This type of fear becomes effective as "it takes familiar objects and transforms them into sources of terror" (244). By presenting these familiar objects in repulsive forms in the gothic narratives, terror arises and thus unfolds this ambivalent relationship between fear and fascination, repulsion and attraction. With the "return of the repressed," the uncanny is in effect. We experience terror, then, when what is repressed comes back, and in hideous forms.

In Powers of Horror, Julia Kristeva offers a completely different concept of horror in her representation of the "abject". Abjection for Kristeva is revulsion and disgust; it hits the self, it is identity crises. Even more violent and fearful than Freud's "Uncanny," Kristeva's "abject" is never at all familiar, what is known and recognizable. Kristeva states,

Essentially different from 'uncanniness', more violent, too, abjection is elaborated through a failure to recognize its kin; nothing is familiar, not even the shadow of a memory. (5)

Kristeva argues that what is unknown, meaningless and ambiguous is the abject itself. Abjection, for Kristeva, is "immoral" and "sinister" (4). She states,

The abject is not an object facing me, which I name or imagine ... The abject has only one quality of the object - that of being opposed to I ... what is abject draws one toward the place where meaning collapses. A certain "ego" that merged with its master, a superego, has flatly driven it away ... To each ago its object, to each superego its abject. (2) 


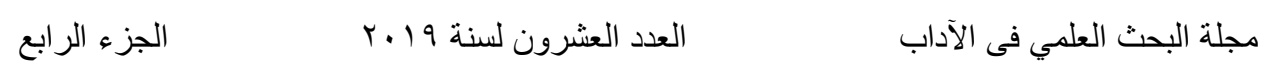

Postmodernism: Between Remembrance and Revival As was mentioned earlier, a key feature of postmodernism is the relation of "recognition and remembrance" of former texts, in reviving classics and literary heritage. Postmodernism introduced new modes of expression in the literary studies to identify the relationship between original texts and the copy or, using Gerard Genette's terms, between "hypotexts" and "hypertexts" $(5,6)$. Many writers and critics advocate the notion of recalling and revisiting old texts ${ }^{3}$. In this context, Ronald Barthes states,

\begin{abstract}
Any text is a new tissue of past citations. Bits of code, formulae, rhythmic models, fragments of social languages, etc., pass into the text and are redistributed within it, for there is always language before and around the text. (39)
\end{abstract}

On her behalf , Kristeva states that "any text is constructed as a mosaic of quotations; any text is the absorption and transformation of another" (66). Besides Barthes and Kristeva's theory of intertexuality, arises Julie Sander's influential study of Adaptation and Approptiation as two models of expression that postmodernists adopt to revisit and revive old texts. According to Sanders, "Adaptation and Appropriation are, endlessly and wonderfully about seeing things come back to us in as many forms as possible" (160). She further states that adaptation is "a specific process involving the transition from one genre to another: novels into film, drama into musical dramatization of prose narrative and prose fiction; or the inverse movement of making drama into prose narrative" (19). For Hutcheon, adaptation is "a product and a process" (Adaptation, 8). Hutcheon further argues that the attraction of adaptation lies in "the simple act of almost but not quite repeating, in the revisiting of a theme with variations" (Adaptation, 115). Furthermore, to introduce the other face of the coin, Sanders posits her theory of appropriation. She states,

Texts feed off each other and create other texts, and other critical studies, literature creates other literature. Part of the sheer pleasure of the reading experience must be the tension between the familiar and the new, and the recognition both of similarity

\footnotetext{
${ }^{3}$ For example, Edward Said's suggestion that "the writer thinks less of writing originally, and more of rewriting" ("On Originality", 135); Jacques Derrida's notion that "the desire to write is the desire to launch things that come back to you as much as possible" $(1985,157)$; Ronald Barthes's declaration that "any text is an intertext" (Theory of the Text, 39); Julia Kristeva also maintains that any text is a "permutation of texts, an intertextuality" (The Bounded Text, 36).
} 
and difference, between ourselves between texts. The pleasure exists, and persists, then, in the act of reading it around, and on (and on). (14)

Differentiating further between both modes, Sanders argues that "an adaptation signals a relationship with an informing source text ... on the other hand, appropriation frequently affects amore decisive journey away from the informing source into a wholly new cultural product and domain" (26). While some critics might see their work in a negative sense as being a copy, imagination and not original, many others appreciate their work and tend to adopt their modes of expressions. In this regard, Sanders states that "we need to view literary adaptation and appropriation from positive vantage point, seeing it as creating new cultural and aesthetic possibilities that stand alongside the texts which have inspired them" (41). Texts thus become a "multi-dimensional space," in which "a variety of writing blend and clash" producing new texts (Barthes, 170) ${ }^{4}$. On her behalf, Hutcheon states that,

what is involved in adapting can be a process of appropriation, of taking possession of another's story, and filtering it, in a sense through one's own sensibility, interest, and talents. Therefore, adapters are first interpreters and then creators. (Adaptation, 18)

The Representations of Violence/The Violence of Representation: Forms of violence vary immensely in the world we live in, hence, the representations of violence take various forms in the world as well as in any literary, political or social field. Although it is a universal phenomenon, but violence, whether physical, psychological or verbal, is a "catch-all-term" that is fluid and difficult to define (Kowaleski, 10). Michael Kowaleski defines violence as "an act of aggression that is usually destructive, antisocial, and degrading in its consequences ant that usually seems deliberate" (7) .

One of the main influential figures in the study of violence is Michel Foucault who furthermore condemns the rationality behind violence. He states,

\footnotetext{
${ }^{4}$ Noteworthy to mention here, Hutcheon's beautiful analogy of the theory of adaptation to the theories of biological science. She states, "stories do get retold in different ways in new material and cultural environments; like genes, they adapt to those new environments by virtue of mutation - in their 'offspring' or their adaptations. And the fittest do more than survive, they flourish" (Theory of Adaptation, 32).

${ }^{5}$ In The Wretched of the Earth, Frantz Fanon posits his concept of "instrumental" violence as counter and revolutionary to the colonial violence; and, thus, the "destructive" violence of the colonizer is removed by the "productive" violence of the colonized (92-96). Thus violence is rationalized and justified for Fanon.
} 
All human behavior is scheduled and programmed through rationality. There is a logic of institutions and in behavior and in political relations. In even the most violent ones, there is rationality. What is most dangerous in violence is its rationality. Of course violence itself is terrible. But the deepest root of violence and its permanence come out of the form of the rationality we use. The idea had been that if we live in the world of reason, we can get rid of violence. This is quiet wrong. Between violence and rationality there is no incompatibility. (299; emphasis

added)

Whether we encounter "progressive" violence for freedom or "repressive" violence for domination, violence should be "condemned, not for what it is used for, but as a form action itself" (Frazer \& Hutchings, 93).

\section{Revisiting Mary Shelley's Legacy: Frankenstein (1818)}

More than two centuries ago, Mary Shelley wrote her legendary tale, Frankenstein, and which is considered till the present day, a myth in the Romantic Gothic fiction ${ }^{6}$. Punter states that "the durability and influence of Mary Shelley's book has been enormous; perhaps no work in the Gothic tradition has entered more fully into the cultural imagination" (106). The novel is much infused with elements of the Gothic fiction, the Romantic Movement, and science fiction.

Although it has a simple plot, but the narrative is unfolded by the most complicated and sophisticated narrative structure. Three stories are unfolded within a complex frame narrative and epistolary form to reveal three different stories from different perspectives: Captain Walton, Victor Frankenstein, and the monster ${ }^{7}$. The first story which opens the book is unfolded through Captian Robert Walton's letters to his sister Margaret of his exciting expeditions as he sets out with his crew to "explore the North Pole and expand his scientific knowledge". After a few letters to his sister informing her of his dangerous experience, Walton and his crew

\footnotetext{
${ }^{6}$ In her preface to the text, Shelley reveals how the novel was written to win a bet or a competition with her friends (Lord Byron and two others) to see who could write the best horror story. After a few days, she had a dream of a scientist creating life and was horrified by his action; that dream was later developed into one of the best horror Gothic fiction.

${ }^{7}$ The frame narrative or nested narrative is a writing technique that sets more than one story within different frames. It helps to provide other points of views and additional voices making a more complex story. The epistolary technique is represented through a collection of letters or different documents, diaries, articles, reports, or others. This style provides much greater sense of realism within the main story.
} 
encounter a gigantic figure which shortly disappears. Later, they rescue a nearly frozen man, Victor Frankenstein, who recovers and tells his own story of the narrative to the Captain ${ }^{8}$. Entering the second frame of the narrative, Victor tells his story: beginning as a young boy with his wealthy family in Geneva, his happy childhood, his obsession with reading about natural philosophy, his study of chemistry at the university, and finally his hideous creation of the monster and its destructive consequences. With this complex structure, the reader is suddenly introduced to another frame: the monster's story, another frame narrative. The nested narrative is rounded with Captain Walton's letters to his sister at the end of the story. Victor Frankenstein, after recovering and seeing Walton's enthusiasm and obsession with scientific discoveries, decides to tell him his tragic tale as a moral story a warning of "how dangerous is the acquirement of knowledge" (53). He states,

You seek for knowledge and wisdom as I once did; and I ardently hope that the gratification of your wishes may not be a serpent to sting you, as mine has been.

As the suspense mood of the story heightens, the reader is intrigued to enter into Frankenstein's frame. Fascinated with "the secrets of heaven and earth," (33) and "animated by an almost supernatural enthusiasm," (51) Frankenstein justifies his temptation for such explorations,

In another studies you go as far as others have gone before you, there is nothing more to know; but in scientific pursuit there is continual food for discovery and wonder.

Delving deeply in his explorations of natural philosophy, chemistry and the study of decayed human parts, consumed by the desire to create a living being, intrigued by the study of the power of lightning after seeing how it destroyed a tree in a storm, Frankenstein resolves in his studies and quest. He states,

So much has been done, exclaimed the soul of Frankenstein more, far more will I achieve; treading in the steps already marked, I will pioneer a new way, explore unknown powers, and unfold to the world the deepest mysteries of creation. (46)

\footnotetext{
${ }^{8}$ Noteworthy, there is a common error among the public presuming that Frankenstein is the name of the monster, whereas it is actually the name of the scientist Victor Frankenstein, who created the unnamed monster.
} 
Fully armed and empowered with knowledge, Frankenstein finally succeeds after two years into bringing his experience into life. However, the creature turns into a gigantic deformed monster.

Repulsed by the horror of his creation, Frankenstein flees into the streets, while the monster he created flees into the forest and disappears after being abandoned and rejected by his creator. As the mood abruptly changes, Shelley displays the natural and inevitable outcomes of the "forbidden knowledge" (Punter, 106) mastered by Frankenstein and his unnatural creation. Cruelly rejected by his creator and the people who see him, hunting him down, the creature realizes its deformity. Reflecting upon its figure, it says, "Was I then a monster, a blut upon the earth, from which all men fled, and whom all men disowned" (141)? Surprisingly, the reader feels sympathy for the creature, as it yields to its deformity and finds solace in the nature of the forest. The monster says,

Half surprised by the novelty of these sensations, I allowed myself to be borne away by them; and forgetting my solitude and deformity, dared to be happy. (168)

However, being more rejected and mistreated, the monster questions the injustice it faces and pities itself: "I, the miserable and the abandoned, am an abortion, to be spurned at, and kicked, and trampled on" (275). The monster then "vowed eternal hatred and vengeance to all mankind" (169). The story is tragically intensified as the monster takes its revenge. Killing William, Frankenstein's youngest brother, and framing his murder to his nanny, Justine, who was convicted and hanged were only the first steps of fulfilling his vows, "the first hapless victims to [his] unhallowed arts" (100).

The narrative dramatically shifts into another frame as the monster tells its own story and justifications in its confrontation with the creator, Frankenstein. Lamenting its creator, the monster says,

Unfeeling, heartless creator! You had endowed me with perceptions and passions, and then cast me abroad an object for the scorn and horror of mankind. (167)

Suffering injustice, rejection, isolation and alienation, the monster longs for companionship and demands Frankenstein to create a female mate for it. Once again, we sympathize with the monster and its natural need for a companion. Reluctantly, Frankenstein agrees after the monster vows to take its companion far away from Europe to Southern America. Frankenstein's fear of creating "a race of devils" (203) urges him to 
destroy the female creature that he started making shortly. Spying upon its creator and seeing him destroy its female mate, leads the monster to threaten more violent revenge. The monster, then, murders Henry Clerval, Frankenstein's best friend, and then kills Elizabeth, Frankenstein's beloved cousin and wife on their wedding night. Overcome with sorrow and grief, Frankenstein's father shortly dies. As all his beloved ones die, Frankenstein laments that he is left with nothing but "an omen, as it were, of [his] future misery" (39). Frankenstein is thus aware of the tragic and destructive consequences of his scientific obsession, the "genius that has regulated [his] fate," (34) and which he calls, "the fatal impulse that led to my ruin" (35). Infused with guilt and anger, Frankenstein vows to hunt the monster down till the far end of the earth, and kill it. The text concludes with the two of them "locked in a perpetual mutual pursuit and conflict" (Punter, 107). Frankenstein, however, dies as he unfolds his story to Walton, and before he achieves his mission. The narrative dramatically intensifies again as Walton surprisingly encounters the monster weeping over Frankenstein's dead body and lamenting his death. The creature disappears into the darkness as it is now ready to die after the tragic death of its creator. The last frame of the narrative ends with Walton resuming his letters to his sister and telling her of the end of the tale. The structure of the nested narrative thus reminds us of the oral Gothic tradition of storytelling.

A postmodern reading of Shelley's myth reveals several interpretations; most notably, the blurring of boundaries and the ambiguities it results in. As each frame is completed, the reader reaches many paradoxical assumptions deduced behind Frankenstein's tale, the monster's tale, and even the authorial voice of Shelley inferred between the lines. The reader is confused by blaming whom for all the violence and tragedy in the text as they see both Frankenstein and his monster sharing in the guilt. Who is the real monster behind the tale? Punter states, "it is Frankenstein who defies God by creating life, but it is the monster who bears at least part of the punishment" (106). Even Shelley's inference of not completely blaming the monster for its violent acts, its revenge, is detected in the feelings of sympathy aroused every now and then. Totally feeling innocent and rejected, the monster tells Frankenstein,

It was dark when I awoke; I felt cold also, and half-frightened, as it were instinctively, finding myself so desolate. Before I had quitted your apartment, on a sensation of cold, I had covered myself with some clothes; but these were insufficient to secure me from the dews of night. I knew, and could distinguish, 
nothing; but feeling pain invade me on all sides, I sat down and wept. (119)

Yet, on the other hand, Shelley cannot blame Frankenstein for hating the monster and rejecting it. Punter argues that,

Mary Shelley's final act of authorial contempt towards the monster whom she, after all, has also 'created,' is a bitter one; she gives him no name, and the consequences of that are only too apparent. (109; emphasis in original)

This is also revealed in the display of the unnatural and hideous appearance of the monster. Feelings of sympathy and disgust are conflicted. In this regard, Punter states,

It appears that she intended to demonstrate the wrongness of Frankenstein's efforts, at the same time as showing the monster as fundamentally morally neutral creature who is made evil by circumstances; but these twin goals sit very uneasily together, and there are many moments when it is difficult for the reader to know whose behavior is the most unjustifiable. (107)

Boundaries are blurred between guilt and innocence, victim and villain, sympathy and disgust, the monster and the scientist, the natural and the unnatural, and life and death. Frankenstein recounts, "Life and death appeared to me ideal bounds, which I should first break through, and pour a torrent of light into our dark world" (54). Thus, as the intention was 'light', the result was 'death'. It is even blurred between the old and the new as the old outdated theories that Frankenstein explores at the beginning of the narrative are opposed to the new, modern theories he studies later at the university.

From another perspective, we see how the image of the grotesque monster fits in Kristeva's notion of the 'abject'. Completely different from Freud's 'uncanny', Shelley's monster is completely "unfamiliar" and "immoral" as Kristeva's 'abject'. Kristeva's description of the 'abject' can thus be matched with Frankenstein's monster,

The corpse, seen without God and outside of science, is the utmost abjection. It is death infecting life. Abject. It is something rejected from which one does not part, from which one does not protect oneself as from and object. Imaginary uncanniness and real threat, it beckons to us and ends up engulfing us. (Kristeva, 4) 
This recalls Frankenstein's description of the physical appearance on the first sight of the monster as it bears life and, which, completely frustrates his expectations,

How can I describe my emotions at this catastrophe, or how dilineate the wretch whom with such infinite pains and care I had endeavored to form? His limbs were in proportion, and I had selected his features as beautiful. Beautiful! - Great God! His yellow skin scarcely covered the work of muscles and arteries beneath; his hair was of a lustrous black, and flowing; his teeth of a pearly whiteness; but these luxuriances only formed a more horrid contrast with his watery eyes, that seemed almost of the same colour as the dun white sockets in which they were set, his shriveled complexion and straight black lips.

Later, when Frankenstein encounters the monster for the first time after its long disappearance, Frankenstein states,

A flash of lightning illuminated the object, and discovered its shape plainly to me; its gigantic stature, and the deformity of its aspect, more hideous than belongs to humanity, instantly informed me that it was the wretched, the filthy daemon, to whom I had given life. (83)

Moreover, the disgusting figure of the Frankenstein's 'abject' arouses horror and revulsion in the reader; while, at the same time, the suspense in the rising dramatic actions and the dark heavy atmosphere create terror throughout the narrative.

Violence takes different forms in the narrative, whether associated with power, or resulting from it. As Frankenstein proceeds with his sinful act, he violates nature; his rejection to the monster is a form of violence associated to his power of knowledge. The violence that results in power is traced in the monster's vengeance and murders as well as Frankenstein's eventual pursuit to avenge his family and friend. Naturally, justifications are in place. From one point, the monster justifies his deeds with his rejection and isolation; and from another point, Frankenstein justifies his pursuit of eternal knowledge and his hatred to the unnatural creature and, finally, his call for revenge. According to Punter,

the book embodies a rational conflict; but these are other levels as well; principally, there is an intense fear of the ugly, the 
unpredictable, the disruptive, which prevents the author from dealing fairly with the monster. Frankenstein may have committed a heinous sin, or a social crime, but in the end he is 'one of us'; the monster may not be wholly blameworthy, even for his later acts of violence, but nonetheless he is different, and must be chastised as such ... Frankenstein, at root, is a book about the rejection of the strange, at both social and psychological levels. (110, 111; emphasis in original)

\section{Ahmed Saadawi: Voicing the Terrors of Baghdad}

Launching the assumed Global War on Terror, the American invasion of Iraq (2003), followed by the military occupation has resulted in sectarian conflicts, ethnic cleansing and endless violence that reveal its consequences till the present day. The ongoing violence was further confronted with counter-violence as seen in the "escalation of battles between guerrilla fighters and occupation troops" (Schwartz, 253). In the multi-ethnic Iraqi national community, the overthrowing of the regime brought all the national, tribal, and sectarian tensions to the surface, along with the "spontaneous outbursts of ethnic violence" (Zeidel, 22). In his illuminating book, War without End: The Iraq War in Context, Michael Schwartz presents a profound study of the Iraqi national and diverse community before, during and after the American and the military occupation to Iraqi. Documenting their daily dramatic lives, Schwartz states that "most residents now lived in walled, effectively cleansed communities. Traveling across the city means hopping from one frontline to another and negotiating countless militia-controlled fiefdoms" (252). According to Schwartz, the Iraqi government, or as he calls it the "Donothing government" was,

notable mainly for its absence ... In no area was this incapacity more visible than in the failure of the government to play even a minor role in the escalating violence within Baghdad. (253)

Moreover, Schwartz states that "sovereignty did not reside in the "puppet government" and had also "slipped away" from U.S. (255). In such anarchy, everything got out of control,

the struggle for the dominance of mixed neighborhoods escalated dramatically. Deadly battles between Shia and Sunni militias involved every available weapon and method, including car bombs and death squads. Minority groups, including Christians, Kurds, and Palestinians, became targets in these drives for ethic purity and were forced to flee or be killed. Ethnic 
cleansing had become central to the spiraling violence in Baghdad. (255)

The U.S. and the military invasion eventually found themselves "swimming against a tide of resistance;" and, because of the Iraqis, the "metaphoric Global War on Terror had been transformed into an endless, hopeless actual war" (Schwartz, 276).

Frankenstein in Baghdad (2013) chronicles Ahmed Saadawi's tragic vision of contemporary Baghdad, the horrors and terrors of living within such disturbing predicaments, and the pain and fear of the Iraqi people ${ }^{9}$. The narrative is Saadawi's attempt in revealing and denouncing violence, as well as, in voicing the terrors of Baghdad. In his awardwinning novel, a junk dealer, Hadi Al-Attag, "haunts the street of the civil war-torn Baghdad of 2005" in search of human body parts to stitch together a human corpse. Coming into life, the corpse "sets out on a journey of revenge for those whose organs constitute his body" (Najjar, arabicliterature.com).

The novel opens on a suicide bombing shaking the Tayaran square in the capital of Iraq,

The explosion was horrific ... the smoke, the burning of plastic and seat cushions, the roasting of human flesh. You wouldn't have smelled anything like it in your life and would never forget it ... It cut electricity wires and killed birds. Windows were shattered and doors blown in. cracks appeared in the walls and some old ceilings collapsed. There was unseen damage too, all inflicted in a single moment. $(20,21)$

Wandering the streets after the explosion, Hadi "watched the scene with eagle eyes, looking for something in particular amid this binge of death and devastation" (21). He finally finds what he has long searched for, a nose; he could finally stitch the last part of the body he has been collecting. We learn later as Hadi recounts his story to a group of journalists in a coffee shop, how he got this unnatural idea. It all started when Hadi's friend, Nahem, died in a car bombing and Hadi's failure to collect his body for burial as "it had been hard to separate Nahem's flesh from that of the horse" (24). Aiming to combine a complete corpse to bury it, Hadi starts collecting human parts from different explosions to

\footnotetext{
${ }^{9}$ The novel was awarded the International Prize for Arabic Fiction 2014, a prize popularly known as the Arabic Booker. The novel makes the Man Booker International's 2018 longlist and was translated by Jonathan Wright.
} 
stitch together and complete his mission. Finding his last piece, at last, Hadi picks it up, "wrapped it in his canvas sack, folded his arm, and left the scene" (22). Going home to finish his mission,

Hadi opened the canvas sack and took out the thing. In recent days, he had spent ours looking for one like it, yet he was still uneasy handling it. It was a fresh nose, still coated in congealed, dark red blood. His hand trembling, he positioned it in the black hole in the corpse's face. It was a perfect fit, as if the corpse had its own nose back. (26)

By stitching the last piece, Hadi finally succeeds in completing his corpse, aiming to give it a "proper burial" (27) instead of being "left in the street like trash" (27). However, as Hadi got wounded in another bombing and returns home, he finds that the corpse had disappeared. We later learn that the soul of an innocent guard who was recently killed in the Bataween explosion has inhabited the corpse's body and gave it life, as it "sinks" into the corpse "filling it from head to toe" (40). Throughout the novel, the hybrid corpse is given no name, it is addressed as the Whatsitsname (or the "What's-its-name"). This "extraordinary composite" (53) is thus made up of disparate body parts and the soul of the guard. Having no name, Saadawi states in an interview that,

[The body] is made up of parts taken from Iraqis of different races, sects and ethnicities, [it] represents the complete Iraqi individual. In other words, the "What's-its-name" is a rare example of the melting pot identities. (Najjar, arabicliterature.com)

As the story unfolds we learn that, as the corpse regains life, it starts its grand mission of revenge, to kill every guilty criminal who has caused the death of the parts that constitute its body. Possessed by the soul of the guard, the Whatsitsname starts killing for justice and revenge because "justice had to be done here on earth, with witness present" (83). Surprisingly, as it starts killing guilty and evil people, parts of its body start falling off and rot. And, in order to complete its "noble mission" (132) and replace the falling parts, it needs to kill more guilty people to get some "spare parts" (150). However, in its endless cycle of death, the Whatsitsname reluctantly had to kill innocent people to replace its fast rotting parts. Almost losing its eyesight, the creature kills an old man in the streets and takes his eyeballs. Although it may not be an "ideal option," (201) as the creature thinks, but it was the best thing to do in order to continue his "noble mission". Absurdly, the creature thinks that "the old man was a sacrificial lamb that the Lord had placed in [his] path" 
(162). The novel ends on a pessimistic note on the future of Iraq, as there is no solution to the endless fear and violence. Returning to his hometown, Mahmoud (the journalist) states, "it was anarchy out there; there was no logic behind what was happening" (273). Saadawi states that his monster is "the fictional representation of the process of everyone killing everyone. This character is the visual representation of the larger crisis, rather than the solution." (Najjar, arabicliterature.com).

Saadawi adopts a narrative frame structure weaving stories told by different people and from different perspectives within Saadawi's main story. We see Hadi telling his story to customers and journalists at the café: Mahmoud, the journalist, who wants to publish his story; the creature itself as it records its story to the journalist; and, in the end, "the writer" who takes after Mahmoud's story. As Mahmoud publishes his story of the creature in his magazine, horror spreads in the city and fear is aroused among the people. Although the body spreads terror in Baghdad and the police bullets do not affect it, we ironically encounter different perspectives as the creature has its own followers (as some people perceive the creature as a "God-sent" means of "salvation"). For example, we see the old Christian woman Eliashu who shelters the creature in her house as she sees in him her son Daniel who was missing twenty years ago in the Iran-Iraq war and whom she keeps denying his death. To her, the creature is her son sent to her by Saint Georges to whom she spent years praying. We also see other followers as the Magician, the Sophist, and also the Enemy (a former officer in the Iraqi government who could not get along with the corrupt forces anymore). We also have the three mad men: the young, the old and the eldest madman who believe that the Whatsitsname is the Savior who has finally arrived to fulfill God's justice on earth. "All of them," states the creature, "believed I was the face of God on earth" (159). Their mission was to help their savior and to hunt down criminals to provide him with the "parts" (150) it needed.

The absurdity pervading the novel is beyond rationality. A recipient of France's Grand Prize for Fantasy, Saadawi masterfully interweaves his fantasy with facts about Baghdad. As Saadawi displays real names of streets and districts, popular Iraqi poets, factual dates of wars, he simultaneously captures the absurdity of the Iraqi predicament through the abundant use of fantasy. As it reflects the general feelings of the absurdity within Baghdad, fantasy is interpreted in multiple ways. For example, we encounter a walking corpse, wandering souls, fortunetellers, astrologers and magicians; but the absurdity is intensified by the people's interpretation of these fantasies. We find the local police man 


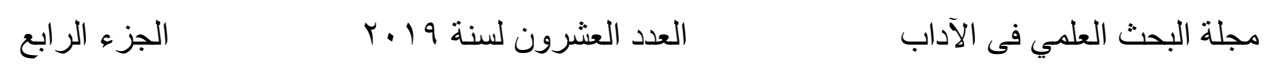

Brigadier Sorour Majid, Head of the Tracking and Pursuit Department, resorting to a fortuneteller to tell him where he could locate the walking corpse to hunt it down, and what were its future plans. Sorour states, "we have analysts, in parapsychology, astrologers, people who specialize in communication with spirits and with the djinn, and soothsayers" (76). Moreover, Ursula Lindesy argues that Saadawi's novel was,

so gothic in its details (a man is troubled after seeing 'blood stain and bits of hair from a scalp'; after another explosion, a man dies alongside his donkey, 'their flesh mixed')that, when the novel makes a turn to the supernatural, it barely shocks. (Lindsey, newyorker.com)

In the interview, Saadawi explains his use of fantasy in the text,

Fantasy is not an escape or alienation from reality. It is rather a way to reach greater depth in this reality, which is packed with fantasy as a daily behavioral and rhetoric practice ... we see fantasy as general headline for the supernatural that prevails over social and popular consciousness. We see it as an inclination to believe illogical explanations or think in a specific spiritual and metaphysical way of salvation from depression and despair. (Hasan, aina.com)

The interweaving of fantasy with reality in the novel thus serves to heighten the absurdity that Saadawi aims to reveal,

Fear of the Whatsitsname continued to spread. In Sadr City they spoke of him as a Wahabi, in Adamiya as a Shiite extremist. The Iraqi government described him as an agent of foreign powers while the spokesman for the U.S. State Department said he was an ingenious man whose aim was to undermine the American project in Iraq. (268)

According to Saadawi, the Whatsitsname has three interpretations: it represents the complete Iraqi citizen since it is made up of different parts from different sects and races; and it represents the savior, taking revenge on behalf of all victims, and bringing justice; and, finally, it is "the epitome of mass destruction and violence" (Najjar, arabicliterature.com).

Once again we encounter violence being rationalized and justified as in Shelley's Frankenstein. From one point, Hadi collects body parts torn from everyday explosions and stitches them to form a corpse in order to give it a proper burial. Hadi tells Mahmoud, "I made it complete so it 


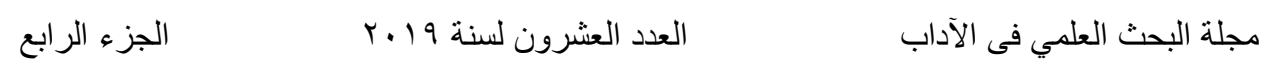

wouldn't be treated as trash, so it would be respected like other dead people and given a proper burial" (27). He has thus made "a composite of victims seeking to avenge their deaths so they could rest in peace" (130). From another part, like Shelley's monster, Hadi's corpse laments being misunderstood and thus rejected, "they have turned me into a criminal and a monster ... this is a grave injustice" (143). However, the reader does not feel the same sympathy that was raised in Shelley's text. It further states,

What's worse is that people have been giving me a bad reputation. They're accusing me of committing crimes, but what they don't understand is that I'm the only justice in this country ... Because I'm made up of body parts of people from diverse backgrounds - ethnicities, tribes, races, and social classes - I represent the impossible mix that never was achieved in the past. I'm the first true Iraqi citizen. $(135,147)$

It does not kill randomly and viciously but rather, it is avenging victims and innocent people from the criminals who killed them. "I was not a murderer," the monster states, "I had merely plucked the fruit of death before it fell to the ground" (162). The Whatsitsname claims that it was on a "prophetic mission," (139) an "exceptional killer ... in the service of truth and justice" (201). Recording its story to Mahmoud's recorder, it says,

I'm the answer to the call of the poor. I'm a savior ... I'm the answer to their call for an end to injustice and for revenge on the guilty. With help of God and Heaven I will take revenge on all the criminals. I will finally bring about justice on earth, and there will no longer be a need to wait in agony for justice to come, in heaven or after death. $(142,143)$

Saadawi's reflection of all these absurd justifications of violence guides the reader to interpret the bigger picture, of those in power and their rationalizations to the occupation and justifications of violence. The city was already in a state of violence before Hadi creates his creature. Saadawi thus reveals the absurdity of the U.S. invasion and military occupation disguised under the Global War of Terror ${ }^{10}$. Resistance and

\footnotetext{
${ }^{10}$ Schwartz further quotes CBS News reporter Lara Logan who provided an online report of the demolished buildings, deserted neighborhoods, and sectarian conflicts caused by the U.S invasion. She states, "they told us they would bring democracy. They promised life would be better than it was under Hussein. But they brought us nothing but death and killing. They brought mass destruction to Baghdad" (Schwartz, 265).
} 
counter-violence turns the city into a complete anarchy where everyone is killing everyone. Scwartz states, "In the eyes of the jihadists, this systematic assault on civilians was justified by the illegality of the occupation" (253). Power is thus in everybody's hands and the resulting violence causes complete chaos in the city.

Saadawi's hypertext is thus an Arabic appropriation of Shelley's Western text. Both Shelley's and Saadawi's nameless creatures have the mission of revenge; but, whereas one avenges itself, the other avenges other victims. Saadawi's novel "isn't a novel about a man playing God, this is a novel about men playing Death" (Carpenter, bookmunch.com). The resulting violence and terror is common in both texts. However, there are some differences to be drawn between the two narratives. The main difference, according to Saadawi is that,

Frankenstein in this novel is a condensed symbol of Iraq's current problems. The Frankenstein-esque atmosphere of horror was strongly prevalent in Iraq during the period covered by the novel. (Najjar, arabicliterature.com)

Moreover, Shelley's creator is a reputable scientist from a wealthy family having a scientific obsession to reach the "unexplored ocean of truth" (35); while Saadawi's creator is an absurd junk dealer, alcoholic, "with bulging eyes, who reeked of alcohol and whose tattered clothes were dotted with cigarette burns" (19). The powerful knowledge of the scientist is absurdly opposed to the ignorance of the junk dealer. From another point, Saadawi's reader does not have the same feeling of sympathy towards the creature as in Shelley's text. Despite the fact that it has its own followers, any sympathy towards the creature is intentionally absent in the novel. Moreover, whereas Shelley's description of her monster is in gothic grotesque arousing horror that fits in Kristeva's 'abject'; we find Saadawi, on the other hand, highlighting more the ongoing terror that the creature arouses in the city. Saadawi's creature is not a gigantic monster, but made up of pieces of human bodies. It could be ugly and deformed, but in the end it looks human. What is more highlighted is the terror it reflects. Representing Freud's 'uncanny', Saadawi's creature manifests "the return of the repressed", and the "familiar". This familiarity is expressed in the novel as the astrologer tries to make sense of the creature's face as it is revealed to him before his death,

This face he had just seen for the first and last time was also from his past. He recognized it, but whose was it? During his slow death throes on the desolate street, he would be wholly convinced 
that it was a composite face, made up of faces from his distant past. It was the face of his own personal past, which he had thought had no face or features. (258)

From one point, it is absurdly familiar since it is a composite of diverse people, representing the Iraqi individual. It is absurdly one of us. From another point, it represents the "return of the repressed" in the sense that it reflects our own repressed fears. It forces us to look into the mirror and face ourselves, to delve deeply in our psyche and withhold responsibility to the justified violence. Saadawi's creature forces the readers to acknowledge their share in the pervasive ongoing violence by blurring the lines between guilt and innocence, victims and criminals, good and evil, life and death. Recounting its story, the creature states,

I was careful about the pieces of flesh that were used to repair my body. I made sure my assistants didn't bring any flesh that was illegitimate - in other words, the flesh of criminals - but who's to say how criminal someone is?

Thus, boundaries are again blurred in Saadawi's text as in Shelley's, one of the prominent elements of postmodernism. Once killing criminals, ended in killing victims, the criminals and victims are entangled. The Whatsitsname resolves to the dramatic conclusion (and which Saadawi subtly infers) that "each one of us has a measure of criminality ... there are no innocents who are completely innocent or criminals who are completely criminals" $(156,214)$. It is Saadawi's way of saying that, in Iraq, everyone is a criminal and everyone is also a victim. The creature has thus become,

a metaphor for a cycle of revenge that keeps perpetuating itself without any end in sight. What begins with a righteous desire to win justice for victims in the lawlessness of post-2003 Iraq soon degenerates into criminality as innocence and guilt become indistinguishable from one another. (Hassan, electrastreet.com)

Saadawi thus delivers his message clearly in the novel that we have all "played a role in creating this creature, in one way or another," (217) by this "evil we all have inside us ... because we are all criminals to some extent" (227). In his interview, Sadaawi states, "if there is a lesson to draw and a moral moment to stop at today as Iraqis, it is to acknowledge 


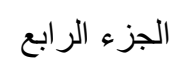

that we are not purely victims and that we have all helped to produce victims in one way or another" (Najjar, arabicliterature.com). If there is an abject in Saadawi's novel, it is Baghdad. Baghdad is the abject, with its haunting souls, its pervasive violence and darkness, its "ominous clouds," (277) and the dead bodies that "littered the streets like rubbish" (153).

In their texts, both Shelley and Saadawi voice the terrors of their societies. Terror, according to Punter, is central to the eighteenth century Gothic literature and which emerged as "an exorsive force for the fears, desires and anxieties that plagued the society as it developed toward capitalism" (23). In this sense, Shelley's Frankenstein thus "articulated fears to do with the power of science, godlessness, social anarchy and privation" (Punter, 23). These issues "re-emerged" with postmodernism as terror becomes "at the centre of political discourse" since the beginning of postmodernism (23). As Shelley voices the terrors of the Romantic era to the "coming of industry" and the "rapidly changing world" (Punter, 112, 23) of scientific discoveries, Saadawi voices "the terrors of war, its violence and the way it distorts the psyche both ethically and emotionally" (Schimmel, majalla.com). According to Sam Metz,

The dystopian elements of the novel are not rooted in its speculative, supernatural elements but rather in the very, real nightmarish violence of 2005 Baghdad. (Metz, losangelesreview.com )

Saadawi's novel could be seen as an Arabic counter-narrative to the American and Western dominant mainstream. Whereas their texts document the trauma of the American experience in Iraq, Saadawi's text is a manifestation of the city's collective pain and fear.

\section{Beyond Frankenstein/Beyond Postmodernism: A Conclusion}

The Gothic and the Postmodernism have, thus, come to be "intertwined" producing what Beville calls a "literary monster" (16). She states,

Its fascination with terror, the negative and the irrational, and its hostility towards accepted codes of reality, place it firmly in the realm of revolution. What is often terrifying is that this revolution is against humanity itself. (16)

Saadawi's "literary monster" thus forces his readers to face their own fears, bringing to surface what has long been "repressed", and to 


$$
\text { الجزء الر ابع }
$$

acknowledge that all "abnormalities that we would divorce from ourselves, are a part of our selves, deeply and pervasively" (Hogle, 12).

The 'abject' and the 'uncanny' thus reflect the monsters within each one of us. Beville states,

Monsters, as projection of abject otherness are subsequently deemed as no longer marginal, but as an intrinsic part of the literary narrative of our postmodern culture. Characters that are presented as vampiric, demonic, alien, or as a manifestation of "the Thing", in Gothic-postmodernist works, evidently suggest psychoanalytic reductions of subjectivity whereby the otherness within the self is repressed and maligned ... The dialogue between self and other is opened up by the initial appearance of the monster, and that dialogue is intensified by the hesitant experience of terror which allows one to reach beyond the self to the realm of unknown otherness. (201-202; emphasis added)

This expresses our "fundamental need" for terror for exposing the "repressed" and for creating a "dialogue" to interpret one's own self and society. It was this "dialogue" with the self that Saadawi sought to open beyond his text. We can thus "hear the mutterings of the desire for a return of terror, for the realization of the fantasy to seize reality" (Lyotard, 82). On his behalf, David Oakes states that gothic literature is:

a literature of destabilization in that it inspires its readers to ask questions about themselves, their society, and the cosmos surrounding them. It serves as a cultural artifact, reflecting the concerns and fears not only of the time in which it is written but also of the time in which it is read. (1)

In order to create this mood of terror in their texts, both Shelley and Saadawi resort to violence: its representations, its justifications, and its consequent destruction. Violence, thus, reflects the real nature of man, "his fundamental disorderliness and will to destruction". Thus,

the artist who deals honestly with violence becomes a kind of a nose-rubber or mirror-holder, someone rubbing the spectator's nose in the disagreeable and holding up a mirror in which he can contemplate the essential filthiness, nastiness, and beastliness of mankind. (Fraser, 109-110) 
Unfortunately, not all violence "is condemned; not all forms of violence receive widespread disapproval" (Stanko, 12). Consequently, as a response to such "banalization of violence" could be a "habituation of fear" (Gupta, 174). We have seen how the use/abuse of violence can be justified in order to reach an end. However, Hannah Arendt argues that "violence can be justified, but it will never be legitimate" (52).

Within social injustice and political violence, Gothic literature helps to achieve understanding. In this regard, Punter states,

The individual comes to see him- or herself at the mercy of forces which in fundamental ways elude understanding. Under such circumstances, it is hardly surprising to find the emergence of a literature whose key motifs are paranoia, manipulation and injustice, and whose central project is understanding the inexplicable, the taboo, the irrational. (112)

Gothic literature thus helps us make sense of the world we live in and helps us understand our own selves deeply.

A postmodern reading to both texts reveals upon more interpretations in this paper, raising more philosophical questions. In Shelley's text, it is the "monstrous self" of the scientist that is exposed, his forbidden desires, his greed, obsessions and dark consciousness. And, after the death of his family and friend, he becomes a living corpse (metaphorically speaking); he represents death in life. Although he is alive, he is dead in spirit. With all the boundaries blurred between good and evil, innocence and guilt, life and death, could this be interpreted in the light of Kristeva's 'abject'? Is Victor Frankenstein the real 'abject' behind the narrative? Besides, it was Frankenstein after all who created the monster; hence, it was Frankenstein who aroused terror in the city. Recalling Kristeva's notion of the abject, we can see that it is the scientist's "superego" that drives him to the "immoral" and the "sinister".

From another point, Saadawi's "uncanny" corpse represents life in death; its body is, paradoxically, alive by the stitched dead parts. Although it is made up of dead parts, it is alive in spirit: in its spirit of revenge, of its noble mission. It is even more "uncanny" and fearful than Shelly's monster. As her hideous description was mentioned only once in the text creating disgust and revulsion, Saadawi's monster represents a continuous means of fear and terror. With every rotting part falling apart, there is an immediate "spare part" to be replaced, with an ongoing hideous call upon the imagination. Ironically, it is an endless cycle of life and death. Protected even from the bullets of the police, the corpse 
becomes an eternal source of fear and terror. As the reader's imagination is triggered with every replaced part (arm, leg, eyeball ...), the source of terror becomes continuous throughout Saadawi's text. Boundaries are again blurred between good and evil, victim and criminal, life and death.

Worth mentioning and investigating also is Saadawi's title. The "Frankenstein" in the title represents the symbol of fear and terror wandering the city of Baghdad. Definitely, a prestigious award-winning writer like Saadawi, inspired by Shelley's myth, must have known that the "Frankenstein" in Shelly's text was the scientist and not the monster. Was Saadawi's use of Frankenstein in the title a deliberate and deep inference to the guilty scientist in Shelly's text as being the source of terror, and who shows up in his text to deliver his message that it is not always the "other" that is guilty; to raise deep philosophical thinking, this "dialogue" with one's self? Or, was Saadawi simply addressing those audience having the common misconception of Shelley's title: that Frankenstein was the name of the monster? And, in so doing, Saadawi thus delivers another message by reflecting the terrors of the people and the chaos of the city, forcing the readers to denounce violence and to acknowledge the fact that no one is a pure innocent. Their silence, their passivity, their justifications, or even their "habituation" of fear should be reconsidered. After all, "sometimes doing nothing is the most violent thing to do" (ZiZek, 217).

Reflecting on what might come after postmodernism, Eva Brann states,

It is, after all, so named to make a next epoch unnamable (though I have heard 'postpostmodernism'). What can possibly come after the time when the "just now" has itself been pushed into the past, when we are said to be already living ahead of our own present? (6)

We might not know what is beyond postmodernism; but what is beyond Frankenstein is more interpretations, more adaptations, more appropriations, more responses and more philosophical questions to be raised. Shelley's and Saadawi's monsters represent us with all our greed and evilness, our forbidden desires, our nihilistic responses towards violence, and our endless justifications in the name of God, or justice, or motherland, or even in the name of values disguised under false ideals. As our repressed fears come to the surface, facing ourselves in the literary mirror, our values that are long buried would also come to surface. Floating above our consciousness, it is these values that define the lines 
blurred between binary oppositions. And, by defining these lines clearly, one's responses change, taking clear and definitive stances in life, seeking a better future.

***** 


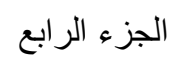

\section{Works Cited}

Arendt, Hannah. On Violence. Orlando: Harcourt Inc., 1969.

Barret, Terry. "Modernism and Postmodernism: An Overview with Art Examples". In Art Education: Content and Practice in a Postmodern Era. Ed. James Hutcheons and Marianne Suggs. Washington: NAEA, 1997.

Barthes, Ronald. "Theory of the Text". Untying the Text: A PostStructuralist Reader. Ed. Robert Paul. London: Routledge and Kegan Paul, 1981.

Beville, Maria. Gothic-postmodernism: Voicing the Terrors of Postmodernity. New York: Radopi, 2009.

Botting, Fred. Gothic. London: Routledge, 1996.

Brann, Eva. "What is Postmodernism?". The Harvard Review of Philosophy, Spring 1992, (4-7).

Butler, Christopher. Postmodernism: A Very Short Introduction. New York: Oxford University Press, 2002.

Carpenter, Daniel. "Completely Worth the Wait" - Frankenstein in Baghdad. Bookmunch. 16 Feb. 2018. Web. 29. Jun. 2018. https://bookmunch.wordpress.com/2018/02/16/completely-worththe-wait-frankenstein-in-baghdad-by-ahmed-saadawi/

Fanon, Frantz. The Wretched of the Earth.1963. Trans. Richard Philcox. New York: Grove Press, 2004.

Foucault, Michel. "Language to Infinity" in Language, Counter-Memory, Practice, trans. Donald F. Bouchard and Sherry Simon. Oxford: Blackwell, 1977.

Frazer, Elizabeth and Elizabeth Hutchings. "Contemporary Political Theory - On Politics and Violence: Arendt Contra Fanon". Contemporary Political Theory (2008) 7, 90-108.

Frazer, John. Violence in the Arts. New York: Cambridge University Press, 1974. 
Freud, Sigmund. "The Uncanny" (1919) in Standard Edition of the Complete Psychological Works. Vol.17, trans. James Strachey. London: Hogarth Press, 1955.

Genette, Gerard. Palimpsests: Literature in the Second Degree. Trans. Channa Newman and Claude Doubinskyl . Lincoln: University of Nebraska, 1997.

Gupta, Sunam. Imagining Iraq. New York: Palgrave Macmillan, 2011.

Hasan, Harith. "Reading Frankenstein in Baghdad". Assyrian International News Agency. 18 Mar. 2014. Web. 5 Apr. 2015. http://aina.org/news/20140318152331.pdf

Hassan, Wail. "Frankenstein in Baghdad". Electra Street. Dec. 2014. Web. 29 Jun. 2018. https://electrastreet.net/2014/12/frankensteinin-baghdad/

Hogle, Jerold, E. The Cambridge Companion to Gothic Fiction. Cambridge: Cambridge University Press, 2002.

Hutcheon, Linda. "Postmodernism" in The Routledge Companion to Critical Theory. Ed. Simon Malpas and Paul Wake. London: Routledge, 2006.

----------, A Theory of Adaptation. New York: Routledge, 2006.

Jameson, Fredric. Postmodernism. Durham: Duke University Press, 1991.

Kilgour, Maggie. The Rise of the Gothic Novel. New York: Routledge, 1995.

King, Stephen. Danse Macabre. London: Futura, 1986.

Kowaleski, Michael. Deadly Musings: Violence and Verbal Form in American Fiction. New Jersey: Princeton University press, 1993.

Kristeva, Julia. Powers of Horror: An Essay on Abjection. Trans. Leon S. Roudiez. New York: Columbia University Press, 1982.

Lindsey, Ursula. "The Novel After the Arab Spring." The New Yorker, 18 May 2014. Web. 20 Mar. 2015. 


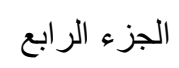

https://www.newyorker.com/books/page-turner/the-novel-afterthe-arab-spring/

Lyotard, Jean-Franois. "What is Postmodernism?" in The Postmodern Condition: A Report on Knowledge. Minneapolis: University of Minnesota Press, 1984.

Metz, Sam. "Fiction of Dystopian Times: Ahmed Saadawi's "Frankenstein in Baghdad". Los Angeles Review of Books, 5 Jun. 2018. Web. 29 Jun. 2018.

Najjar, Al-Mustafa. "Iraqi Author Ahmad Saadawi: 'The Novel Implicitly Questions This Concept of Salvation'." Arabic Literature (in English), 26 March 2014. Web. 4 Feb. 2015. https://arablit.org/2014/03/26/iraqi-author-ahmad-saadawi-thenovel-implicitly-questions-this-concept-of-salvation/

Oakes, David A. Science and Destabilization in the Modern American Gothic. London, Greenwood Press, 2000.

Punter, David. The Literature of Terror Vol.1. New York: Longman, 1996.

Saadawi, Ahmed. Frankenstein in Baghdad. 2013. Trans. Jonathan Wright. New York: Penguin Books, 2018.

Sanders, Julie. Adaptation and Appropriation. London: Routledge, 2006.

Schimmel, Noam. "New Writing from the Arab World." Majalla, 31 Aug. 2012. Web. $20 \quad$ Mar. 2015. http://eng.majalla.com/2012/08/article55233812/new-writingfrom-the-arab-world/

Shelley, Mary Wollstonecraft. Frankenstein 1818, or the Modern Prometheus. New York: Signet Classics, an Imprint of New American Library, a Division of Penguin Group, 2013.

Schwartz, Michael. War Without End: The Iraq War in Context. Chicago: Haymarket Books, 2008. 


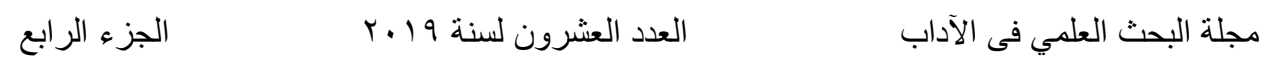

Stanko, E. "Introduction: Conceptualizing the Meanings of Violence", in The Meanings of Violence, ed. E. Stanko. London: Routledge, 2003.

Varma, Devendra P. The Gothic Flame. London: Arthur Barker, 1957.

Zeidel, Ronen. "The Iraqi Novel and the Kurds". In Review of Middle East Studies, vol.1,45, no.1 (Summer 2011), 19-34.

Zezek, Slavoj. Violence. London: Profile Books, 2008. 